\section{From 'The Map' to an Internalized Concept. Developing a Method of Deconstruction as Practice for Reflexive Cartography}

Gl_Forum 2019, Issue 2 Page: 194 - 205

Full Paper

Corresponding Author: michael.lehner@uni-due.de DOI: 10.1553/giscience2019_02_s194

\author{
Michael Lehner, Jana Pokraka and Inga Gryl \\ University of Duisburg-Essen, Germany
}

\begin{abstract}
John Brian Harley's canonical paper 'Deconstructing the map' (1989) has been one of the main bases of Critical Cartography, Critical GIScience, and reflexive approaches to working with maps and geomedia in geography education. However, reducing deconstruction mainly to reading the map's margins is only part of the potential that deconstruction offers. In this paper, following Derrida's approach of deconstruction more closely, we build on the discussion of Harley's paper and try to develop a deconstructive practice for reflexive cartography in educational contexts.
\end{abstract}

\title{
Keywords:
}

deconstruction, maturity, education, spatial citizenship, map-reading, poststructuralism, critical cartography

\section{Introduction and background}

In their literature review on cartography, Gryl and Kanwischer (2011) identify a gap concerning reflexive map work (pp. 190-191) - that is, most of the literature examined offers methods for a better understanding of 'the map', but only partly provides techniques for a better understanding of the map-makers' intentions. However, reflexive map work tries to go beyond an intention-oriented demand and critically asks for the margins of the author's intention and, more importantly, for the margins of the socially perceived norm, to be made explicit.

This gap was tackled by the reflexive map education approach (Gryl 2009, Gryl 2012) and the Spatial Citizenship approach alike (Gryl \& Jekel, 2012; Jekel, Gryl, \& Oberrauch, 2015). Both approaches are rooted in critical cartography, while the Spatial Citizenship approach focuses on spatial-societal participation through the reflexive use of geomedia, such as (digital) maps. One central source of inspiration for both approaches was Harley's (1989) canonical paper 'Deconstructing the Map', with its influential idea that maps could be treated as 'texts'. Harley's paper opened the way for the so-called linguistic turn in the cartographic debate, as well as for post-structuralist arguments.

Lehner et al. (2018) focused on a re-reading of Harley's paper, contrasting his perspective on the deconstructing of maps, which is partly based on Derrida, with their own approach to 
deconstruction, which was based mainly on Derrida. To show the epistemic differences between the two authors, Lehner et al. (ibid.) focused on a comparison between the structuralist approach of Saussure (Hoffmann, 2010, pp. 39-57; Saussure, 1931) and the poststructuralist approach of Derrida, emphasizing that Harley uses Derridean terminology (Lehner et al., 2018, pp. 148-150). Lehner et al. suggest a practice of deconstructing the map which tends towards hermeneutics/structuralism, rather than deconstruction. Thus, Harley's interpretation of Derrida can be taken further and the approach of critical cartography extended, to a methodological approach that goes beyond existing work in reflexive map education and Spatial Citizenship.

A central argument put forward by Lehner et al. (2018) is that Harley's approach preserves 'the map' as an object of reflection and does not treat it consistently as 'text' in a Derridean, post-structuralist manner. Based on this discussion that contrasts Harley and Derrida, the paper highlighted specific potentials and limitations of Harley's approach, as illustrated in Table 1, and drew attention to earlier critics who focused on Harley's eclecticism (Belyea, 1992).

Table 1: potentials and limits of Harley's approach (Lehner et al., 2018, p.153)

\begin{tabular}{|c|c|}
\hline Potentials & Limits \\
\hline $\begin{array}{l}\text { Potential to question the influence of } \\
\text { e.g. institutions on 'the map'... }\end{array}$ & but not the institutions as such; \\
\hline $\begin{array}{l}\text { Potential to understand 'the map' as an } \\
\text { instrument of power... }\end{array}$ & $\begin{array}{l}\text { but power-relations are treated as means } \\
\text { to an end, to... }\end{array}$ \\
\hline $\begin{array}{l}\text { question and uncover implied ideologies of } \\
\text { 'the map'... }\end{array}$ & but not power-relations as such. \\
\hline $\begin{array}{l}\text { With the focus on the creation and the } \\
\text { impact of 'the map', Harley's approach } \\
\text { enables a critical interpretation of 'the } \\
\text { map'... } \\
\text {... }\end{array}$ & $\begin{array}{l}\text { but its critical potential is focused on } \\
\text { the specific map itself. }\end{array}$ \\
\hline
\end{tabular}

A Derridean-style deconstruction shifts the focus from reflecting on 'the map' within its power relations to a specific kind of self-reflection. This kind of self-reflection is based on Derrida's perspective on reading, which he sees as an interpretation that takes us outside of the writing toward a psychobiographical signified' (Derrida, 1997, p. 159). Lüdemann describes this way of reading as the production of a new text, which is closely linked to the text that we read but which at the same time has a specific character due to the reader's own particularities and experiences (Lüdemann, 2013, p. 78). Summarized, this specific kind of self-reflection would be a reflection of the 'text' that is produced through the reading. This perspective on reading should offer the potential to take the reader 'outside of the writing [or map]' (Derrida, 1997, p. 159) and could help to question institutions or power relations more directly. These considerations are coherent with the theoretically (Schneider 2010) and empirically validated differentiation between reflection, as externalized map critics, and reflexivity, as questioning thinking and acting with a map, in Gryl (2012). Furthermore, the Spatial Citizenship approach 
is also aware that map-reading involves the production of hypotheses (MacEachren 1995) and strongly suggests reflexivity in the production of one's own hypotheses ('text production' in a Derridean sense) (Gryl \& Jekel 2012). Nevertheless, this reflexivity was still deeply rooted in Harley-inspired critical cartography. This paper, however, will suggest a method that is based more on Derrida's deconstruction, and so bring out the full potential of Harley's pioneering idea.

This approach will be fruitful, as we are convinced that a Derridean practice of map-reading offers great potential for educational contexts, notably to foster what Adorno (1971) calls 'maturity' ('Mündigkeit'). Adorno describes the struggle for maturity as a tension between internalization1 on the one hand, and resistance or dissent on the other. A Derridean deconstructive practice offers the potential to uncover what has been internalized, or internalized concepts 2 , and to become self-aware, which we regard as an important basis in the permanent process of becoming mature.

Before providing a methodological framework for a potential practice for deconstructive mapreading, we would like to summarize the insights (based on Lehner et al. 2018) that might function as guidelines for the essentials of a method of deconstruction:

- principle A: The specific kind of self-reflection enabled by deconstructive mapreading helps to uncover and identify map-readers' internalized concepts.

- $\quad$ principle B: Deconstructive map-reading helps to perceive these internalized concepts as constructed and historically grown, and makes them discussable.

- principle C: Deconstructive map-reading shows the map as a medium that is discussable and part of power dynamics.

- principle D: Deconstructive map-reading turns the normalization or internalization effect of the communicated map upside-down.

\section{Method, Design and Results}

\subsection{Method and Design}

Driven by these reflections on deconstruction (Derrida, 1997) and 'Deconstructing the Map' (Harley 1989), we tried to develop a deconstructive practice for reflexive map-reading in educational contexts that could be evaluated according to the principles outlined above. Inspired by Schmied-Kowarzik's (2008) discussion about dialectics of theory and practice in pedagogics, we developed a guided worksheet for a deconstructive map-reading that should

\footnotetext{
${ }^{1}$ We see 'internalization' as being rooted in socialization and education (Berger, \& Luckmann, 2012, p. 139; Habermas, 1972; Hurrelmann, 2008).

2 We use 'concept' for terms that structure perception (e.g. 'power', 'ethnicity') and are precursors to constructions while being constructions themselves (see Kuckartz, 2018, p. 36; Schnell, Hill, \& Esser, 2008, pp. 128-129). We see the combination of these two strands, 'internalization' and 'concept', as a single but complex element of the socially constructed 'norm' and 'abnormal'.
} 
help (1) to put our thoughts on deconstruction into practice, and (2) to revise the method used to deconstruct the map in the light of experience gained from our practice.

To initiate the process of deconstruction, we had the opportunity to implement our thoughts on deconstruction during a 'Society and Space' course for student teachers in primary social and science education at the University of Duisburg-Essen, in the winter semester of 2018/19. With a group of eleven students, we tested and discussed the first draft of our worksheet. The students applied the tasks given on the worksheet to a political map of Europe. Afterwards, they shared their comments on every step of the worksheet with us and the group.

In section 2.2 below, we present each step of the worksheet to suggest a practice of deconstructive map-reading that remains close to Derrida's theories while also being suitable for use in the classroom. We explain our ideas concerning the method's design. Following this, we present the results of the students' deconstructive map-reading as a basis for a later evaluation of the worksheet, where we compare the results with our principles from section 1. The presentation and evaluation of the results is based on qualitative content analysis (Bohnsack, 2014; Kelle \& Kluge, 2010; Kuckartz, 2007, 2018; Mayring, 2015). We decided to discuss the worksheet's design and to present its results in the same section (section 3, 'Discussion and Reflection') in order to illustrate the circular character of the method, where theory and praxis feed into each other.

\subsection{Theory and Practice of a deconstructive map-reading}

Deconstructive map-reading should include four aspects (see Figure 1), which the worksheet divides into 8 tasks or steps, described in detail in what follows.

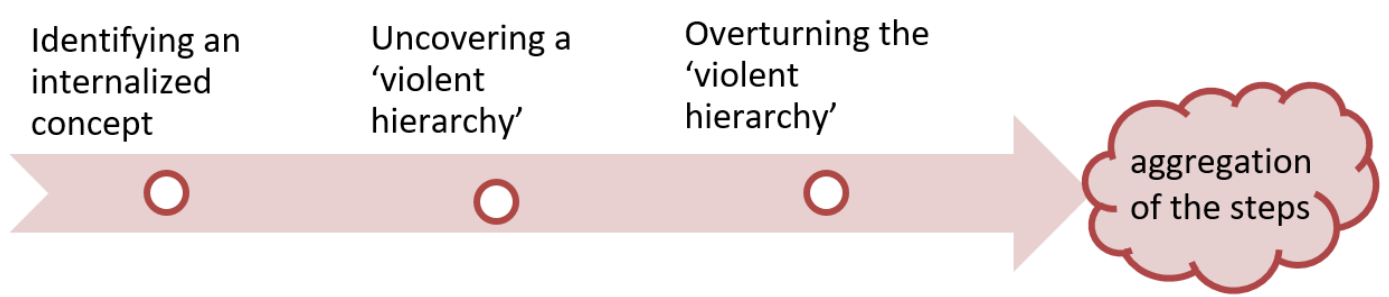

Figure 1: The four major aspects of a practice for a deconstructive map-reading (authors' own design)

\section{Aspect 1: Identifying an internalized concept}

Step 1 helps to record what Derrida calls the 'psychobiographical signified' (Derrida, 1997, p. 159) - a 'text' that is produced through the reading (of the map), as discussed above (see section 1). Following Adorno's (1971) argumentation, we think that this new 'text' produced through subjective reading has the potential to represent internalized concepts. Therefore, we developed two further steps (Steps 2 and 3) which create the foundation for self-reflection that derives from a deconstructive practice.

In Step 2, we simply ask students to note down what they recognize on the map (in our case, a map of Europe). We then ask them to go over what they have written to enrich it with just 
one term that seems particularly meaningful - that is, a specific term corresponding to an internalized concept (Adorno, 1971).

Table 2: Identifying an internalized concept

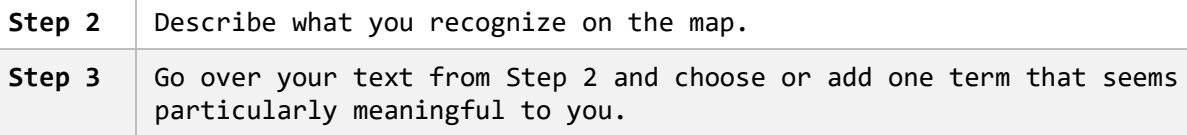

The students' confrontation with the political map of Europe evoked two categories of concepts. 3 The first comprises variations of the concept of border, which we grouped using the 'code' content-oriented concepts. This category is fairly dominant, and nine of the eleven students aggregated their map-reading with the term 'border' (4 students) or terms linked to it, like 'boundary', 'demarcation', 'belonging', 'European countries' and 'countries' (1 student each). The second category of concepts we identified is more abstract and focuses on aspects of the map's design. We coded these as design-oriented concepts and included the terms 'colourful' and 'centre' (1 case each) in this category.

While we think that reflecting on content-oriented concepts offers great potential to foster maturity, we did not at first glance really expect the category design-oriented concepts and reflecting on it to imply great potential for fostering the political subject. The new 'text' produced through subjective reading is still closely linked to the 'text' (map) that has been read, as Lüdemann (2013, p. 78) claims. This relation between the two hints at the more abstract design-oriented concepts reflection on which does not seem to be too promising in fostering the political subject. Nevertheless, these more abstract concepts do have the potential to turn the normalizing effect of the communicated map upside-down, as we will try to show below.

\section{Aspect 2: Uncovering a 'violent hierarchy'}

Although internalized concepts (such as 'country' or 'border') were uncovered and identified by the reading of the map, we cannot assume that the subjective meaning ('signified') of the term itself (the 'signifier') chosen in Step 3 was uncovered at this stage. We follow Saussure (1931), who argues that meaning ('signified') derives from differences between 'signifiers'. For example, the meaning of 'active' derives from the difference from 'passive'. Thus, mediated by the concept of a system of differences, Saussure breaks with the idea that language represents the world: rather, he sees language as a system that produces meaning and reality (world $x$ language $<->$ subject). Thus, to clarify the meaning of the internalized concept in Step 3, in Step 4 we ask for its opposite in order to construct an awareness of differences.

Derrida partly follows Saussure but diverges from the structuralist argumentation with his alternative concept of 'différance'. With this, he criticizes the idea implicit in the structuralists' argumentation of a natural connection between meaning ('signified') and speaker. He sees 'différance' - a constant process of producing and reproducing metaphors of (hidden) meaning ('signifier of the signifier') -before conscious articulation. With the concept of 'différance',

\footnotetext{
${ }^{3}$ We follow Kuckartz (2018, p. 35) in our terminology and use 'category' and 'code' as synonyms.
} 
Derrida decentres the subject (world $\times$ language $x$ subject). But more importantly, 'Différance' also involves the idea that 'in a classical philosophical opposition we are not dealing with a peaceful coexistence of a vis-à-vis, but rather with a violent hierarchy' (Derrida, 2004, p. 39). This becomes clear if we apply the concept of a 'violent hierarchy' to binary oppositions such as 'homo'/'hetero', 'woman'/'man', etc.

Inspired by these Derridean thoughts, in Step 5 we ask students to arrange the opposites from Step 4 according to a subjectively perceived hierarchy. In Step 6, we then ask them to describe this hierarchy in order to uncover more clearly the 'violent hierarchy' that is implied in language (from a Derridean perspective), and to open up the potential for a better intersubjective comprehensibility.

Table 3: Uncovering a 'violent hierarchy'

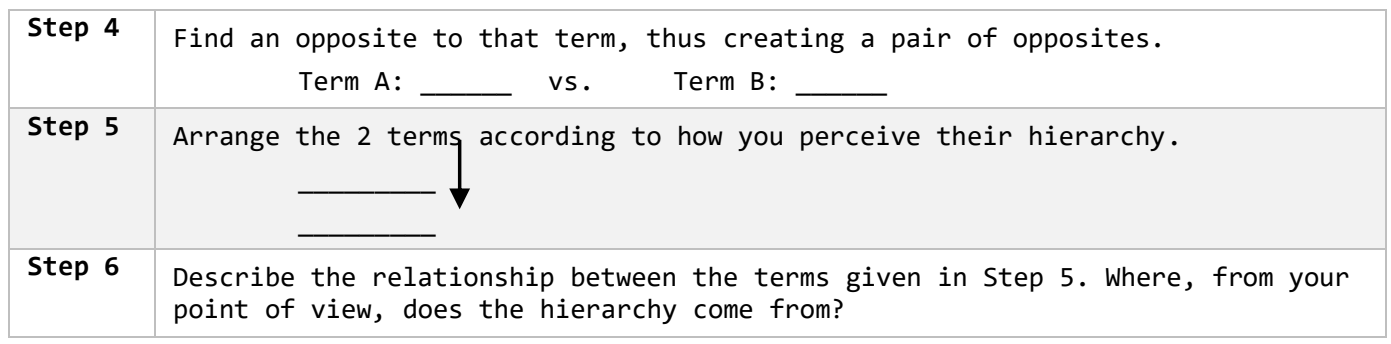

The students chose the following opposites and arranged them hierarchically as shown:

- 'border' $\rightarrow$ 'freedom' (2 students)

- 'border' $\rightarrow$ 'openness'

- 'border' $\rightarrow$ 'borderless'

- 'boundary' $\rightarrow$ 'borderless'

- 'demarcation' $\rightarrow$ 'connectedness'

- 'exclusion' $\rightarrow$ 'belonging'

- 'European countries' $\rightarrow$ 'European community'

- 'waters' $\rightarrow$ 'countries'

- 'colourful' $\rightarrow$ 'monochrome'

- 'periphery' $\rightarrow$ 'centre'

\section{Aspect 3: Overturning the 'violent hierarchy'}

So far, this approach for a deconstructive practice should have helped to uncover an internalized concept and show its embeddedness in a 'violent hierarchy'. However, deconstruction tries to go further. It aims to defer that hierarchy, and with that the meaning of specific 'terms' or concepts (see Derrida, 2009, pp. 64-68). But how? As an example, in Gender Trouble (1990), Judith Butler deconstructs 'The compulsory order of sex/gender/desire' in just two pages (pp. 9-11). Butler also starts her deconstruction with a pair of opposites: 'sexed body' and 'gendered subject'. After describing the hierarchy of these 'terms', Butler focuses on their interrelations, and with that she 'overturns' their 'violent hierarchy': 
If the immutable character of sex is contested, perhaps this construct called 'sex' is as culturally constructed as gender; indeed, perhaps it was always already gender, with the consequence that the distinction between sex and gender turns out to be no distinction at all. (pp. 10-11)

With this description of the interrelation between 'sex' and 'gender', Butler 'overturns' the hierarchy and presents the seemingly natural (or 'prediscursive') category 'sex' as having a discursive, or a historical/genealogical, character. Based on Butler's practical example of deconstruction, in the next two steps we ask students to describe the interrelations between their chosen terms, and to display them graphically for further clarification:

Table 4: Overturning the 'violent hierarchy'

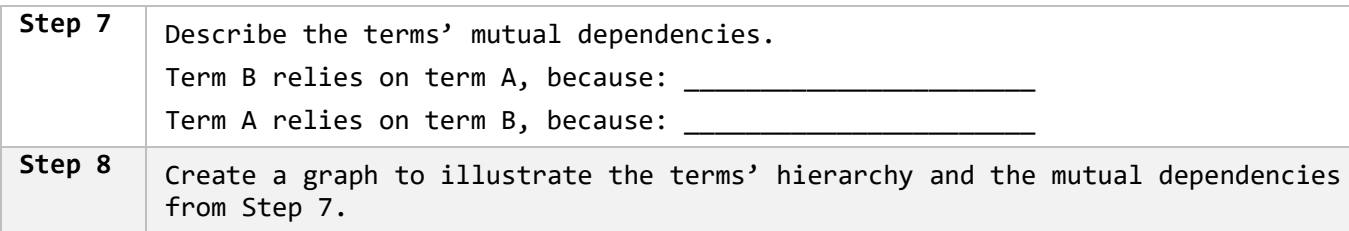

To analyse the students' results, we created three 'codes'. We called the first one dialectical thinking and applied it to every case where we were able to identify the search for the interrelationship of the pairs of opposites. Due to the framing of Step 7 , it was not surprising that the code was applicable to every student answer except one, where the answer was simply too short to clearly apply the code. We could see the production of variations of the terms' meanings in the students' notes. We interpret this production of variations as being, potentially, indicative of movement. Although we do not know whether the internalized concepts like 'border' identified by the students were prediscursive or perceived as natural before, with this step we show that they are now perceived as discursive.

While we expected to apply the 'code' dialectical thinking to almost every case, we tried to analyse the terms' variations and movement more deeply, and so created the codes synthesis and open movement. To operationalize these codes, we applied the code synthesis to identify a pair of opposites that had been merged in a new term incorporating them both. We applied the code open movement in cases where we did not see any such merger. 4 The results of this analysis are shown in Table 5.

\footnotetext{
${ }^{4}$ The coding process is inspired by 'consensual coding' (Hopf \& Schmidt, 1993): we applied the coding as a group of seven people and discussed our differences.
} 
Table 5: Analysis of dialectical movement

\begin{tabular}{|l|l|l|}
\hline field of tension & \multicolumn{1}{|c|}{$\begin{array}{l}\text { 'open } \\
\text { movement' }\end{array}$} & 'synthesis' \\
\hline 'border' <-> 'freedom' & & $\mathrm{x}$ \\
\hline 'border' <-> 'freedom' & $\mathrm{x}$ & \\
\hline 'border' <-> 'openness' & too little information to apply a code \\
\hline 'border' <-> 'borderless' & & 'border transgression' \\
\hline 'boundary' <-> 'borderless' & $\mathrm{x}$ & $\mathrm{x}$ \\
\hline 'demarcation' <-> 'connectedness' & $\mathrm{x}$ & \\
\hline 'exclusion' <-> 'belonging' & $\mathrm{x}$ & $\mathrm{x}$ \\
\hline 'European countries' <-> 'European community' & $\mathrm{x}$ & $\mathrm{x}$ \\
\hline 'waters' <-> 'countries' & & \\
\hline 'colourful' <-> 'monochrome' & & \\
\hline 'periphery' <-> 'centre' & & \\
\hline
\end{tabular}

As this table shows, we applied the code open movement for most cases. We would argue that the code dialectical thinking could be applied to these cases as well, which means that in these cases the internalized concepts are open to discussion. At the same time, we think that the cases where we applied the code synthesis need further discussion. Derrida argued that deconstruction fosters the potential for a new 'term' to emerge which it would not be possible simply to extrapolate from the previous classification system (Derrida, 2009, pp. 66-67). These 'terms' or concepts that we emphasized with our code synthesis, such as 'borderless' and 'border transgression', are not new in Derrida's sense of 'new term', which tries to overcome metaphysical thinking. Nevertheless, we think these concepts are very interesting. Remember: we started with a political map of Europe, where we see the idea of the nation-state represented quite prominently, but some students came up with concepts like 'borderless' and 'border transgression' in their process of (critical) reflexive map-reading.

One final aspect we would like to emphasize here is the link between the 'text' that is produced through reading and the 'text' (map) that has been read, mentioned in section 3.2.1. If we take a closer look at more abstract design-oriented concepts like 'colourful' and 'centre', reflection on which does not seem particularly promising in fostering the political subject, it shows up quite clearly in Step 7 that these concepts are still linked to the 'text' that has been read (i.e. the map). For example, the student who came up with the field of tension 'colourful' vs 'monochrome' discussed the focus on Europe which appears 'colourful' in contrast to other continents, which are 'monochrome':

The Continent is displayed in different colours. In order to differentiate the continent, the countries are coloured differently. Continents outside the [map's] focus are displayed as monochrome and not differentiated. (Student's note; own translation.) 
While we couldn't find a synthesis such as 'eurocentrism' in the students notes, this suggests that the student identified a tension between the emphasis of Europe and the devaluation of other continents.

\section{Aspect 4: Aggregation of Steps 1-8}

Up to this point, the different parts of the procedure do not seem to mesh, and therefore we tried to design a final step to aggregate the 8 steps. We experimented with different tasks. For example, we asked students to link the mutual dependencies from Step 7 to concrete representations on the map which are subjectively apparent to the students. In another task, we asked for a comparison of Step 5 ('Arrange the two terms according to how you perceive their hierarchy') and Step 7 (mutual dependencies) and hoped for an explicit description of the 'overturn' of the 'violent hierarchy'. Due to redundancy and the attempt to keep the procedure as simple as possible, we skipped these steps in its latest version. We simply ask in the 9th and final step for new pairs of opposites based on the 'text' of Steps 7 and 8 .

Table 6: Aggregation

Step $9 \quad$ Try to identify new pairs of opposites based on Steps 7 and 8 .

We think this last task offers a good balance between consolidating the work done in the previous steps on the one hand, and an openness that avoids a new rigid re-construction on the other. We illustrate the results of this step in Table 7 by giving answers by a student who started with a content-oriented concept ('border') and those of a student who started with an designoriented concept ('colourful').

Table 7: Aggregation results

\begin{tabular}{|l|l|}
\hline content-oriented concept & design-oriented concept \\
\hline universal - individual & $\begin{array}{l}\text { Continents which aren't being focused on / } \\
\text { continents which are being focused on }\end{array}$ \\
\hline individual - state & not differentiated - differentiated \\
\hline orientation - disorientation & starting point - endpoint \\
\hline self-determination - common good & \\
\hline satisfaction - dissatisfaction & \\
\hline
\end{tabular}

We think these examples provide a hint as to the potential of this approach. We started with a political map of Europe, and here we have a cloud of words that is full of tensions (e.g. 'individual - state') which can serve as a basis for discussions that reach beyond looking at maps critically - concepts that are oriented towards hermeneutics and understanding, and reflecting on one's own involvement in political discourses. 


\section{Discussion and Reflection}

The potential of this approach goes far beyond deconstructing map-reading, but we are also aware that deconstructive map-reading is not about a fixed result, which would simply impose another rigid (re-)construction. We think the strength of this approach lies in the process of deconstruction itself, one central part of it (laid out in Steps 1 and 2) being to encourage the uncovering of internalized concepts (principle A)).

As discussed in section "Aspect 1: Identifying an internalized concept", we think that contentoriented concepts such as 'border' and its variations represent an internalized concept more directly than do design-oriented concepts, such as 'colourful' and 'centre'. In section 2, we defined the internalized concept as a jigsaw piece of the socially-constructed norm, or of what is considered abnormal. We think that the content-oriented concepts meet the requirements of this definition: for example, the concept 'border' can be seen as a precursory concept (a jigsaw piece) of the construction of the 'nation-state' as a norm.5 The exclusionary differences derived from the socially-constructed norm or (ab)normal linked to this construction (such as the differentiation between citizens and non-citizens of nation-states) contrasts with the universalism of human rights (Habermas, 2011, p. 31),6 or the anti-essentialist attempt of deconstruction (Engelmann, 2009, pp. 17-19).

While we think that content-oriented concepts represent internalized concepts more directly than the design-oriented concepts, we believe that the latter offer a specific quality of reflection. With their focus on design-based decisions in map-creation, such concepts facilitated discussion of questions such as 'What is colourful/monochrome?' or 'What is displayed in the centre/periphery?'. Based on the link between the 'text' produced through reading and the 'text' (map) that has been read, students identified a tension between, for example, those continents on which there was a focus and those which did not appear in detail. In designoriented concepts, we recognize decisions made during map-creation as discursive elements and as a part of power dynamics (principle D).

In section "Aspect 3: Overturning the "violent hierarchy", we argued that the content-oriented concepts and design-oriented concepts located within 'violent hierarchies' are discussable (principle B), because of the interrelations between the terms in each pair of opposites. This perception of concepts as being open to discussion implies principle C.

To sum up: the shift in focus from a critical understanding of the map (see Table 1) to the 'text' that is produced through reading the map is the core idea of this approach. The approach should foster a specific kind of reflection and should make it possible to turn the normalization or internalization effect of the communicated map upside-down (principle D).

\footnotetext{
${ }^{5}$ For a detailed discussion of the history of the idea of the nation and the nation-state, see e.g. Anderson (1988) and Hobsbawm (2005). For a discussion of nationalism and racism within the discipline of geography based on the example of the Department of Geography at the University of Vienna around 1938, see Svatek (2018).

${ }^{6}$ For a discussion of the contradiction between civil rights that are linked to citizenship and human rights, see e.g. Denninger (2009).
} 
While these insights seem promising, to evaluate the potential of our approach for geography education in a school-based context we are aware that further empirical research is required with primary or secondary school students. An adaption might be considered crucial, especially as the final step (aggregation) necessarily leaves students with open ends. This final step could, however, serve as a starting point for addressing the power relations in their own classes as perceived subjectively by the students themselves.

\section{References}

Adorno, T. W., \& Becker, H. (1971). Erziehung zur Mündigkeit Vorträge und Gespräche mit Hellmut Becker 1959 - 1969 (25.). Frankfurt: Suhrkamp.

Anderson, B. (1988). Die Erfindung der Nation. Frankfurt am Main: Campus-Verl.

Belyea, B. (1992): Images of power: Derrida, Foucault, Harley. In: Cartographica (The International Journal for Geographic Information and Geovisualization) 1992, no. 2, pp. 1-9.

Berger, P. L., \& Luckmann, T. (2012). Die gesellschaftliche Konstruktion der Wirklichkeit (24th ed.). Frankfurt am Main: Fischer Taschenbuch.

Bohnsack, R. (2014). Rekonstruktive Sozialforschung: Einfübrung in qualitative Methoden (9., überarbeitete und erweiterte Auflage). Opladen Toronto: Verlag Barbara Budrich.

Butler, J. (1990). Gender Trouble: Feminism and the Subversion of Identity. New York: Routledge.

Crampton, J.W. (2010). Mapping. A Critical Intro-duction to Cartography and GIS. Malden

Denninger, E. (2009). 'Die Rechte der Anderen'. Menschenrechte und Bürgerrechte im Widerstreit. Kritische Justiv, (3), 226-239.

Derrida, J. (1990). Die Struktur, das Zeichen und das Spiel im Diskurs der Wissenschaft vom Menschen. In P. Engelmann (Ed.), Postmoderne und Dekonstruktion: Texte französischer Philosophen der Gegenwart (pp. 114-139). Stuttgart: Reclam.

Derrida, J. (1997). Of grammatology. (G. C. Spivak, Trans.). Baltimore: Johns Hopkins University Press.

Derrida, J. (2004). Positions. (A. Bass, Trans.). Chicago: University of Chicago Press.

Derrida, J. (2006). Die Schrift und die Differen₹. (R. Gasché \& U. Köppen, Trans.) (12th ed.). Frankfurt am Main: Suhrkamp Verlag.

Derrida, J. (2009). Positionen: Gespräche mit Henri Ronse, Julia Kristeva, Jean-Louis Houdebine, Guy Scarpetta. (P. Engelmann, Ed., D. Schmidt \& A. Wintersberger, Trans.) (2nd ed.). Wien: Passagen.

Engelmann, P. (2009). Positionen 2009. In Positionen: Gespräche mit Henri Ronse, Julia Kristeva, Jean-Louis Houdebine, Guy Scarpetta (2nd ed., pp. 11-21). Wien: Passagen.

Feustel, R. (2015). Die Kunst des Verschiebens: Dekonstruktion für Einsteiger. Verlag Wilhelm Fink.

Glasze, G. (2009). Kritische Kartographie. Geographische Zeitschrift, 181-191.

Gryl, I. (2009). Kartenlesekompetenz: Ein Beitrag zum konstruktivistischen Geographie-unterricht (= Materialien zur Didaktik der Geographie- und Wirtschaftskunde 22). Wien.

Gryl, I. (2012): Geographielehrende, Reflexivität und Geomedien. Zur Konstruktion einer empirische begründeten Typologie. In: Geographie und ihre Didaktike (GuiD) 40, 4, 161-182.

Gryl, I., \& Jekel, T. (2012). Re-centring Geoinformation in Secondary Education: Toward a Spatial Citizenship Approach. Cartographica: The International Journal for Geographic Information and Geovisualization, 47, 18-28. https://doi.org/10.3138/carto.47.1.18

Gryl, I., \& Kanwischer, D. (2011). Geomedien und Kompetenzentwicklung - ein Modell zur reflexiven Kartenarbeit im Unterricht. Zeitschrift Für Didaktik Der Naturwissenschaften, (17), 203-222.

Habermas, J. (1972). Thesen zur Theorie der Sozialisation: Stichworte und Literatur zur Vorlesung im SommerSemester 1968. Frankfurt am Main.

Habermas, J. (2011). Zur Verfassung Europas: Ein Essay. Suhrkamp Verlag. 
Harley, J. B. (1989). Deconstructing the Map. Cartographica, 26, 1-20. https://doi.org/10.3138/e6357827-1757-9t53

Hobsbawm, E. J. (2005). Nationen und Nationalismus Mythos und Realität seit 1780 (3rd ed.). Frankfurt, Main [u.a.]: Campus-Verl.

Hoffmann, L. (Ed.). (2010). Sprachwissenschaft: ein Reader (3., aktualisierte und erw. Aufl). Berlin ; New York: De Gruyter.

Hopf, C., \& Schmidt, C. (Eds.). (1993). Zum Verbältnis von innerfamilialen sozialen Erfahrungen, Persönlichkeitsentwicklung und politischen Orientierungen: Dokumentation und Erörterung des methodischen Vorgehens in einer Studie zu diesem Thema. Hildesheim.

Hurrelmann, K. (Ed.). (2008). Handbuch Sozialisationsforschung (7., vollst. überarb. Aufl). Weinheim: Beltz. Jekel, T., Gryl, I., \& Oberrauch, A. (2015). Education for Spatial Citizenship: Versuch einer Einordnung. GW-Unterricht, 137, 5-13.

Kelle, U., \& Kluge, S. (2010). Vom Einzelfall zum Typus: Fallvergleich und Fallkontrastierung in der qualitativen Sozialforschung (2., überarb. Aufl). Wiesbaden: VS, Verl. für Sozialwiss.

Kuckartz, U. (2007). Einführung in die computergestützte Analyse qualitativer Daten: Lehrbuch (2., aktualisierte und erw. Aufl). Wiesbaden: VS, Verl. für Sozialwiss.

Kuckartz, U. (2018). Qualitative Inhaltsanalyse: Methoden, Praxis, Computerunterstützung (4. Auflage). Weinheim Basel: Beltz Juventa.

Lehner, M., Pokraka, J., Gryl, I., \& Stuppacher, K. (2018). Re-Reading Spatial Citizenship and ReThinking Harley's Deconstructing the Map. GI_Forum, 1, 143-155. https://doi.org/10.1553/giscience2018_02_s143

Lüdemann, S. (2013). Jacques Derrida zur Einführung (3rd ed.). Hamburg: Junius.

MacEachren, A. M. (1995): How maps work. Representation, visualization, and design. New York.

Mayring, P. (2015). Qualitative Inhaltsanalyse: Grundlagen und Techniken (12., überarbeitete Auflage). Weinheim Basel: Beltz.

Pickles, J. (Ed.). (1995). Ground truth: The social implications of geographic information systems. New York: Guilford Press.

Saussure, F. de. (1931). Grundfragen der allgemeinen Sprachwissenschaft. Berlin: de Gruyter.

Schmied-Kowarzik, W. (2008). Das dialektische Verhältnis von Theorie und Praxis in der Pädagogik. Kassel University Press.

Schneider, A. (2010): Der Zweite Blick in einer reflexiven Geographie und Didaktik. Dissertationsschrift. Jena.

Schnell, R., Hill, P. B., \& Esser, E. (2008). Methoden der empirischen Sozialforschung (8., unveränd. Aufl). München: Oldenbourg.

Schuurman, N. (2000). Trouble in the heartland: GIS and its critics in the 1990s. Progress in Human Geography, 24(4), 569-590. https://doi.org/10.1191/030913200100189111

Svatek, P. (2018). Kontinuität oder Wandlung? Stadt- und Landesplanung am Geographischen Institut der Universität Wien um 1938. GW-Unterricht, 1, 5-13. https://doi.org/10.1553/gw-unterricht152s5 